JURNAL SPORTA SAINTIKA

P-ISSN 2502-5651

E-ISSN 2579-5910

\title{
Pengaruh Pemberian Whey Protein Terhadap Pengurangan Gejala Kerusakan Otot Setelah Aktivitas Eksentrik
}

\author{
Reno Siska Sari \\ IKIP Budi Utomo Malang \\ Renosiska87@gmail.com
}

\begin{abstract}
Eccentric activity is one of the types of resistance activity that often causes muscle damage which usually begins within 24 hours and peaks within 48 hours after exercise. Muscle damaged leads to loss of muscle strenght, increased muscle sorness reduced range of motion, increased inflammation and an increase in concentrations of myofibre proteins in the blood. Stimulating protein synthesis and minimizing protein breakdown (proteolysis) are the two cellular processes that are essential for muscle recovery after damage. The aim of the present study was to prove the effect of whey protein supplementation on the reduction of muscle damaged symptoms after eccentric activity. The design of this research is randomized group pre-test and post-test design. The subjects of this study were students of PJKR, IKIP Budi Utomo, who were randomly divided into two groups, 22 respondents ofcontrol group and 22 respondents of treatment group. The eccentric activity performed was drop jumps on the bench with a height of 0.5 meters. Whey protein is given after eccentric activity about 20 $\mathrm{g} /$ subject. In this study, whey protein supplied in powder form dissolved in $240 \mathrm{ml}$ of mineral water. Whey protein was given immediately after eccentric activity, 24 and 48 hours after eccentric activity ( 3 days during recovery). Measurement of Leg muscle strength was performed using Back and Leg Dynamometer, whereas ROM measurements were measured using a goniometer. The survey results revealed that administration of whey protein intake in the treatment group after eccentric activity can increase leg muscle strength at 48 hours $(72,3 \pm 16,1 \mathrm{~kg})$ hours with $\mathrm{p}=\mathrm{p}=0,003(\mathrm{p}<0,05)$ and 72 hours $(80,3 \pm 17,2)$ with $p=0.00(p<0,05)$ whereas the feeding of whey protein in the treatment group after eccentric activity can improve ROM knee joint at 72 hours $(130,8 \pm 3,1)$ with $p=$ $0.00(p<0,05)$ Thus can concluded that wheyprotein administration of $20 \mathrm{~g} /$ day after eccentric activity can reduce muscle damged by increase leg muscle strength at 48 and 72 hours and knee joint ROM at 72 hours.
\end{abstract}

Key words : Whey protein, eccentric exercise, muscle damaged

\begin{abstract}
Abstrak
Aktivitas eksentrik adalah salah satu jenis aktivitas resistance yang sering menimbulkan kerusakan otot, yang dimulai dari 24 jam setelah aktivitas dan mencapai puncaknya pada 48 jam setelah aktivitas. Kerusakan otot menyebabkan hilangnya kekuatan otot, menurunkan range of motion sendi, meningkatkan inflamasi dan konsentrasi protein miofibril dalam darah. Rangsangan sintesis protein dan meminimalisasi muscle protein breakdown (proteolisis) adalah dua proses seluler yang penting untuk pemulihan setelah


JURNAL SPORTA SAINTIKA

P-ISSN 2502-5651

E-ISSN 2579-5910

kerusakan otot. Tujuan dari penelitian ini adalah untuk membuktikan pengaruh suplementasi whey protein terhadap pengurangan gejala kerusakan otot setelah aktivitas eksentrik. Subjek penelitian ini adalah mahasiswa PJKR IKIP Budi Utomo yang dibagi secara acak ke dalam dua kelompok, 22 orang coba kelompok kontrol dan 22 orang coba kelompok perlakuan. Desain penelitian ini adalah randomized group pretest and posttest design. Aktivitas eksentrik yang dilakukan adalah aktivitas Drop Jumps pada bangku dengan ketinggian 0.5 meter. Whey protein diberikan setelah aktivitas eksentrik sebanyak 20 gram/subjek. Dalam penelitian ini whey protein diberikan dalam bentuk serbuk yang dilarutkan dengan $240 \mathrm{ml}$ air mineral. Waktu pemberian whey protein dilakukan segera setelah aktivitas eksentrik, 24 dan 48 jam setelah aktivitas eksentrik (selama 3 hari pemulihan). Pengukuran kekuatan otot tungkai menggunakan back and leg dynamometer sedangkan pengukuran ROM sendi menggunakan alat goniometer. Dari hasil penelitian diketahui bahwa pemberian asupan whey protein pada kelompok perlakuan setelah aktivitas eksentrik dapat meningkatkan kekuatan otot tungkai pada 48 jam $(72,3 \pm 16,1 \mathrm{~kg})$ dengan nilai $p=0,003(p<0,05)$ dan pada 72 jam $(80,3 \pm 17,2)$ dengan nilai $p=0,00 \quad(p<0,05)$. Pemberian asupan whey protein pada kelompok perlakuan setelah aktivitas eksentrik juga dapat meningkatkan ROM sendi lutut pada 72 jam $(130,8 \pm 3,1)$ whey protein sebesar 20 gram /hari setelah aktivitas eksentrik dapat meningkatkan kekuatan otot tungkai lutut pada jam ke 48 dan 72 serta ROM sendi pada jam ke 72 .

Kata kunci : Whey protein, latihan eksentrik, kerusakan otot.

\section{PENDAHULUAN}

Exercise-induced muscle damaged atau kerusakan otot akibat latihan merupakan fenomena yang umum terjadi setelah latihan yang tidak terbiasa atau latihan dengan intensitas dan durasi yang meningkat (Byrne et al, 2004). Kerusakan otot merupakan kegagalan setiap tingkat mempertahankan keseimbangan antara paparan stres dengan respon terhadap stres. Kegagalan di tingkat atomik menyebabkan kerusakan di tingkat molekuler, kegagalan di tingkat molekul menyebabkan kerusakan di tingkat seluler dan kegagalan di tingkat seluler menyebabkan kerusakan di tingkat jaringan. (Purwanto, 2013). Burnley et al. (2010) mengatakan bahwa gejala- gejala kerusakan otot yang umumnya terjadi akibat latihan meliputi nyeri (soreness), penurunan kekuatan otot, penurunan range of motion (ROM), peningkatan respons inflamasi, peningkatan jumlah serum creatine phosphokinase dalam darah.

Dalam kaitanya terhadap aktivitas fisik atau latihan Jenis latihan yang berdampak pada timbulnya gejala kerusakan otot serta membutuhkan waktu pemulihan paling lama adalah jenis latihan yang menggunakan prinsip high-force 
JURNAL SPORTA SAINTIKA

P-ISSN 2502-5651

E-ISSN 2579-5910

eccentric muscle actions seperti latihan ketahanan (resistance), plyometrics serta downhill running (Street et al., 2011). Pada penelitian sebelumnya dijelaskan bahwa kontraksi eksentrik memberikan bukti kerusakan otot yang lebih besar daripada kontraksi isometrik dan konsentrik (Byrne et al., 2004)

Latihan eksentrik merupakan latihan yang melibatkan suatu pemanjangan otot dan secara bersamaan berupaya untuk berkontraksi maksimal (Eston et al., 2003). Selama latihan eksentrik terjadi peningkatan tegangan (tension) dari otot tersebut dibandingkan saat latihan isometrik maupu isotonik. Tingginya tegangan yang dihasilkan tersebut mengakibatkan seringnya terjadi kerusakan dan pengurangan pada kekuatan otot (Bompa, 1999). Kerusakan serabut otot akibat latihan yang melibatkan pemanjangan otot akan memicu serangkaian reaksi dan interaksi yang kompleks diantara sintesis dan degradasi protein. Pergantian protein (protein turnover) meningkat pesat, tingkat degradasi protein akan mengalahkan laju sintesis protein, sehingga terjadi peningkatan dalam penguraian protein otot (muscleprotein breakdown) yang mengakibatkan degenersi otot. Perubahan dalam ultrastruktur protein ini yang umumnya menyebabkan gejala fisiologis seperti penurunan kekuatan otot, nyeri otot, dan terganggunya fugsi otot (Cooke et al., 2010).

Rangsangan sintesis protein dan meminimalisasi muscleprotein breakdown (proteolisis) adalah dua proses seluler yang penting untuk pemulihan setelah kerusakan otot (Rennie et al, 2006). Meningkatkan laju sintesis protein setelah latihan eksentrik penting dalam mencapai positive net muscle protein balance atau keseimbangan protein otot yang positif. Keseimbangan protein otot yang positif diperlukan selama waktu tertentu untuk mengganti protein otot yang rusak ataupun untuk membangun otot (Jackman, 2011). Pemberian suplemen protein setelah sesi latihan eksentrik akan meningkatkan pengiriman asam amino ke dalam otot sehingga dapat meningkatkan sintesis protein dan meminimalkan degradasi protein sehingga menghasilkan penurunan kekuatan otot yang lebih kecil serta mempercepat pemulihan kerusakan otot (Cooke et al., 2010).

Whey protein merupakan salah satu dari dua jenis protein utama yang berasal dari susu sapi, terbentuk pada saat proses pemisahan susu sapi menjadi keju. Semua unsur yang terkandung dalam whey protein menyediakan asam amino dan kaya akan BCAA (Branched Chain Amino Acids) yang berperan 
JURNAL SPORTA SAINTIKA

P-ISSN 2502-5651

E-ISSN 2579-5910

penting untuk sisntesis protein otot dan pemulihan (Hoffman \& Falvo, 2004). Dibandingkan dengan suplemen protein biasa, whey protein lebih efektif untuk meningkatkan asam amino dalam darah dan sintesis protein karena kinetika penyerapan yang lebih cepat dan konsentrasi asam amino essensial yang lebih tinggi (Cooke et al., 2010).

Penelitian lain menyatakan bahwa kemampuan dari whey protein dalam merangsang sintesis protein otot dikaitkan dengan perbandingan komposisi asam amino yang terkandung pada whey protein sangat mirip dengan komposisi otot rangka manusia, whey protein menyediakan hampir semua asam amino yang diperkiraan sebanding dengan rasio pada otot (Ha \& Zemel 2003). Terdapat respon anabolik setelah mengkonsumsi 20 gram whey protein segera setelah latihan eksentrik yang ditandai dengan peningkatan konsentrasi asam amino dalam darah dan terjadinya keseimbangan protein yang positif (Tipton et al., 2006). Berdasarkan penelitian tersebut, pada penelitian ini digunakan whey protein dengan dosis 20 gram.

Analisis kerusakan serabut otot setelah latihan eksentrik dapat dilakukan dengan dua metode yakni secara langsung ( direct method) dan secara tak langsung (inderect method). Pengukuran secara langsung dengan menggunakan biopsi otot, serta magnetic resonance imaging techniques (MRI). Pemeriksaan kerusakan otot secara tidak langsung dapat dilakukan dengan pemeriksaan serum creatin kinase dalam darah, analisis protein otot, DOMS, kemampuan fisik (motor performance), kekuatan otot (Castro et al., 2011), aktivitas electromyographic (EMG), range of motion (ROM) (Kauranen et al., 2001).

Berdasarkan uraian diatas perlu dilakukan penelitian mengenai pengaruh pemberian suplemen whey protein terhadap pengurangan gejala kerusakan otot setelah latihan eksentrik. Dalam penelitian ini penilaian gejala kerusakanan otot dilakukan dengan metode tidak langsung (indirect method) yakni pengukuran kekuatan otot dan ROM sendi. Pengukuran kekuatan otot dan ROM sendi sebagai indikator untuk melihat fungsi otot setelah latihan eksentrik. Kekuatan otot yang diukur adalah pada bagian otot tungkai sedangkan ROM sendi diukur pada sendi lutut (fleksi dan ekstensi). 


\section{METODELOGI PENELITIAN}

\section{Jenis Penelitian}

Jenis penelitian yang dilakukan adalah penelitian eksperimenal laboratoris, dengan rancangan penelitian yang digunakan adalah Randomized control group pre test and post test design (Zainuddin, 2011).

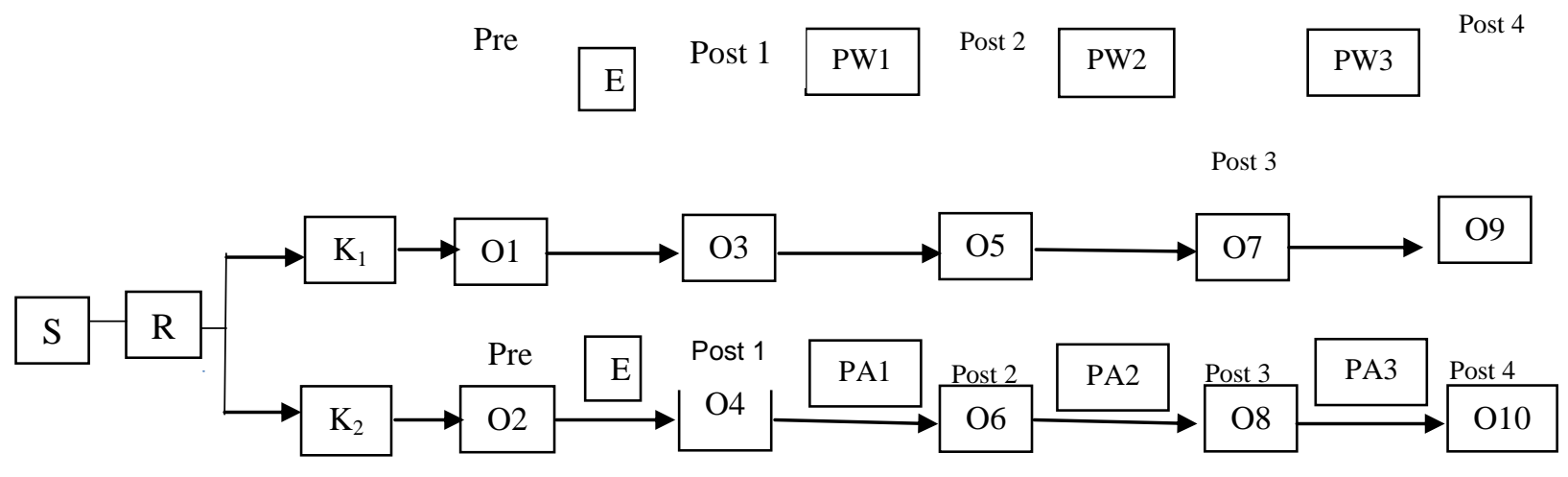

Keterangan :

S

: Sampel Penelitian

R : Randomisasi

K1 : Kelompok kontrol yang diberikan air mineral

K2 : Kelompok perlakuan (suplemen whey protein 20 gram)

$\mathrm{O} 1$ dan $\mathrm{O} 2$ : Pre test pada kelompok K1 dan K2

O3 dan $\mathrm{O} 4$ : Post test 1 pada K1 dan K2 ( 1 jam setelah aktivitas eksentrik)

O5 dan $\mathrm{O} 6$ : Post test 2 pada K1 dan K2 ( 24 jam setelah aktivitas eksentrik)

$\mathrm{O} 7$ dan $\mathrm{O} 8$ : Post test 3 pada K1 dan K2 (48 jam setelah aktivitas eksentrik)

O9 dan 010 : Post test 4 pada K1 dan K2 (72 jam setelah aktivitas eksentrik)

E : Aktivitas eksentrik (drop jumps 10 set 10 repetisi)

PW1 : Pemberian whey protein segera setelah post test 1

PW2 : Pemberian whey protein setelah 24 jam aktivitas eksentrik

PW3 : Pemberian whey protein setelah 48 jam aktivitas eksentrik

PA1 : Pemberian air mineral segera setelah post test 1

PA2 : Pemberian air mineral setelah 24 jam aktivitas eksentrik

PA3 : Pemberian air mineral setelah 48 jam aktivitas eksentrik 
Waktu pelaksanaan penelitian ini adalah bulan Januari 2019 dan dilaksanakan di laboratorium PJKR IKIP Budi Utomo Malang. Populasi dari penelitian ini adalah mahasiswa jurusan PJKR Ikip Budi Utomo Malang. Subjek penelitian yang digunakan dalam penelitian ini adalah laki-laki dengan kriteria inklusi usia 21-24 tahun, sudah tidak melakukan aktivitas eksentrik intensif selama satu bulan terakhir, tidak sedang mengkonsumsi suplemen apapun, tidak memiliki riwayat penyakit ginjal dan tidak riwayat keluarga menderita penyakit ginjal, tidak memiliki kelainan kardiovaskuler dan sistem respirasi yang diseleksi dengan PhysicalActivity Readiness Questionnaire (PAR-Q) revisi 2002 salinan dari Canadian Society for Exercise Physiology, tidak intolerance terhadap susu sapi, memiliki anggota gerak bawah yang baik, tidak sedang mengalami cidera otot, memiliki indeks massa tubuh yang normal $\left(20,1-25,0 \mathrm{~kg} / \mathrm{m}^{2}\right)$. Besar subjek yang digunakan dalam penelitian ini didapatkan melalui rumusRosner (2010) :

$n=\left(\frac{Z \alpha+Z \beta}{x 1-x 2}\right)^{2} X \pi$

$n=\left(\frac{1,96+0,842}{60 \%-95 \%}\right)^{2} \times 30 \%$

$n=\left(\frac{2,35}{0,122}\right)^{2}$

$n=19,26 \sim 20$

Keterangan :

$$
\begin{array}{ll}
n & =\text { Jumlah sampel } \\
\alpha & =0,05 \\
Z \alpha & =\text { Deviat baku alfa untuk } \alpha=0,05 \text { sebesar } 1,96 \\
\beta & =20 \% \\
Z \beta & =\text { Deviat baku beta untuk } \beta=20 \% \text { sebesar } 0,842 \\
\pi & =30 \% \\
x_{1}-x_{2}= & \text { Selisih minimal rerata yang dianggap bermakna }
\end{array}
$$

Berdasarkan rumus diatas dibutuhkan 20 orang untuk setiap kelompok. Total subjek yang dibutuhkan adalah sebanyak 40 orang. Menghindari kemungkinan sampel error, (f) $\pm 10 \%$ sehingga replikasi dikalikan $n / 1-f$ (Higgins dan Kleibun, 1995) sehingga 20/1-0,1 = 22,2 22 orang. Jumlah replikasi pada 
JURNAL SPORTA SAINTIKA

P-ISSN 2502-5651

E-ISSN 2579-5910

penelitian ini baik untuk kelompok kontrol dan perlakuan masing-masing 22 orang. Pembagian subjek yang memenuhi kriteria inklusi untuk kelompok kontrol maupun kelompok perlakuan ditentukan dengan memisahkan berdasarkan nomor urut ganjil dan genap. Subjek dengan nomor urut ganjil ditetapkan sebagai kelompok kontrol sedangkan subjek dengan nomor genap ditetapkan sebagai kelompok perlakuan.

\section{Bahan dan Alat Penelitian}

Bahan-bahan yang digunakan dalam penelitian ini adalahair mineral dan Whey Protein dalam bentuk powder (bubuk) dengan merek terdaftar dari Ultimate Nutrition $^{\circledR}$ Prostar Whey $^{T M}$. Dalam penelitian ini dibutuhkan alat yang membantu dalam pengambilan data, yang meliputi, box (kotak) setinggi $50 \mathrm{~cm}$ untuk melakukan drop jump, continental scale corp untuk mengukur tinggi badan dan berat badan, dynamometer untuk menggukur kekuatan otot tungkai, goniometer untuk mengukur range of motion (ROM) dari sendi lutut, stethoscope (Litmann, mercury Sphygmomamometer), stopwatch untuk mengukur waktu aktivitas eksentrik dan tensimeter

\section{Prosedur Pelaksanaan Penelitian}

Melakukan pemeriksaan kesehatan awal yakni dilakukan dengan wawancara, pemeriksaan fisik yaitu pemeriksaan tekanan darah, denyut jantung, serta suhu tubuh subjek penelitian. Subjek penelitian diberikan penjelasan sebelum mengikuti penelitian (information for consent) kemudian dilakukan persetujuan informed consent oleh subjek penelitian. Sebelum pengambilan data, subjek diberikan sarapan pagi dengan jumlah dan jenis yang sama. Satu jam setelah sarapan pagi subjek diminta untuk melakukan pengukuran awal (pre test) kekuatan otot tungkai dan ROM sendi lutut. Setelah pre test subjek penelitian diminta melakukan aktivitas eksentrik berupa aktivitas drop jump sebanyak 10 set dan 10 repetisi, dengan waktu recovery 1 menit diantara set. Satu jam setelah aktivitas eksentrik dilakukan pengukuran kekuatan otot tungkai dan ROM sendi lutut pada kedua kelompok penelitian(post test 1). Segera setelah post test 1 , dilakukan pemberian suplemen whey protein pada kelompok perlakuan $\left(\mathrm{K}_{2}\right)$ dan pemberian air pada kelompok kontrol $\left(\mathrm{K}_{1}\right)$. 
JURNAL SPORTA SAINTIKA

\section{P-ISSN 2502-5651}

E-ISSN 2579-5910

Selanjutnya, pengukuran kekuatan otot tungkai dan ROM sendi lutut dilakukan 24 jam setelah aktivitas eksentrik (post test 2). Segera setelah post test 2 dilakukan pemberian suplemen whey protein pada kelompok perlakukan $\left(\mathrm{K}_{2}\right)$ dan pemberian air pada kelompok kontrol $\left(\mathrm{K}_{1}\right)_{\text {., }}$ dan dilakukan kembali pengukuran kekuatan otot tungkai dan ROM sendi lutut 48 jam setelah aktivitas eksentrik (post test 3). Segera setelah post test 3 dilakukan pemberian suplemen whey protein pada kelompok perlakukan $\left(\mathrm{K}_{2}\right)$ dan pemberian air pada kelompok kontro $\left(\mathrm{K}_{1}\right) . \mathrm{I}$, dan dilakukan kembali pengukuran kekuatan otot tungkai dan ROM sendi lutut 72 jam setelah aktivitas eksentrik (post test 4). Analisis data pada penelitian ini menggunakan analisis deskriptif, uji normalitas, uji-t (paired) dan independent sample t-test.

\section{HASIL PENELITIAN}

Analisis deskriptif dilakukan untuk mengetahui sebaran data variabel umur dan IMT sebagai variabel kendali dan data variabel tergantung yaitu kekuatan otot tungkai dan ROM sendi lutut pre test, post test 1, post test 2, post test 3 dan post test 4 .

\begin{tabular}{|l|l|l|}
\hline Variabel & Kelompok Kontrol (K1) & Kelompok Perlakuan (K2) \\
\hline Umur (tahun) & $22,3 \pm 0,5$ & $21,8 \pm 0,7$ \\
IMT $\left(\mathrm{kg} / \mathrm{m}^{2}\right)$ & $21,6 \pm 1,5$ & $22,7 \pm 2,4$ \\
\hline
\end{tabular}

Tabel 1. Analisis Deskriptif Umur dan Indeks Massa Tubuh (IMT)

Tabel 2. Analisis Deskriptif Kekuatan Otot Tungkai (Kg)

\begin{tabular}{|l|l|l|}
\hline Kekuatan Otot Tungkai & \multicolumn{2}{|l|}{ Rerata \pm SD } \\
\cline { 2 - 3 } & $\mathrm{K} 1$ & $\mathrm{~K} 2$ \\
\hline Pretest & $74,4 \pm 19,4$ & $82,5 \pm 16,4$ \\
\hline Post test 1 & $64,7 \pm 21,3$ & $70,2 \pm 17,6$ \\
\hline Post test 2 & $58 ;{ }^{\prime}, 7 \pm 16,5$ & $71,2 \pm 18,2$ \\
\hline Post test 3 & $57,2 \pm 17,2$ & $72,3 \pm 16,1$ \\
\hline Post test 4 & $62,2 \pm 18,1$ & $80,3 \pm 17,2$ \\
\hline
\end{tabular}


JURNAL SPORTA SAINTIKA

\section{P-ISSN 2502-5651}

E-ISSN 2579-5910

Hasil analisis deskriptif data kekuatan otot tungkai pada kelompok kontrol (K1) menyatakan bahwa terjadi penurunan rerata kekuatan otot tungkai pada 1 jam, 24 jam, 48 jam setelah aktivitas eksentrik. Namun pada 72 jam setelah aktivitas eksentrik mulai mengalami sedikit peningkatan dibandingkan dengan jam 24 dan 48 jam setelah aktivitas eksentrik. Sedangkan pada kelompok perlakuan (K2) juga mengalami punurunan kekuatan otot tungkai pada 1 jam, namun pada 24 jam dan 48 jam setelah aktivitas eksentrik mulai mengalami sedikit kenaikan dan pada 72 jam setelah aktivitas eksentrik kekuatan otot tungkai semakin meningkat mendekati rerata sebelum aktivitas eksentrik.

Tabel 3. Paired Sampel T-Test Kekuatan Otot Tungkai Kelompok Kontrol (K1) dan Perlakuan (K2)

\begin{tabular}{|l|l|l|}
\hline \multirow{2}{*}{ Variabel } & \multicolumn{2}{|l|}{$\mathrm{p}$-value } \\
\cline { 2 - 3 } & $\mathrm{K} 1$ & $\mathrm{~K} 2$ \\
\hline Pre test-post test 1 & 0,000 & 0,000 \\
\hline Pre test-post test 2 & 0,000 & 0,000 \\
\hline Pre test-post test 3 & 0,000 & 0,000 \\
\hline Pre test-post test 4 & 0,000 & 0,017 \\
\hline Post test 1-post test 2 & 0,012 & 0,867 \\
\hline Post test 1-pos test 3 & 0,007 & 0,242 \\
\hline Post test 1-pos test 4 & 0,765 & 0,000 \\
\hline Post test 2-post test 3 & 0,082 & 0,001 \\
\hline Post test 2-post test 4 & 0,000 & 0,000 \\
\hline Post test 3-post test 4 & 0,000 & 0,000 \\
\hline
\end{tabular}

Berdasarkan tabel 3 terlihat bahwa pada kelompok perlakuan terjadi penurunan kekuatan otot tungkai setelah aktivitas eksentrik hal ini dapat dilihat dari hasil uji tberpasangan pre test dengan pos test 1 dengan hasil berbeda bermakna $(p=0,000)$. Hasil uji t berpasangan kekuatan otot tungkai kelompok perlakuan pada 1 jam dengan 24 jam setelah aktivitas eksentrik menunjukkan tidak dapat perbedaan yang bermakna dengan nilai $p=0,867$. Diketahui bahwa 1 jam setelah aktivitas eksentrik, kelompok perlakuan diberikan asupan whey 
JURNAL SPORTA SAINTIKA

\section{P-ISSN 2502-5651}

E-ISSN 2579-5910

protein, dengan demikian dapat dikatakan bahwa pada 24 jam setelah pemberian whey protein belum dapat meningkatkan kekuatan otot. Kemudian uji $t$ berpasangan kekuatan otot tungkai kelompok perlakuan pada 1 jam dengan 48 jam setelah aktivitas eksentrik juga tidak terdapat perbedaan yang bermakna dengan nilai $p=0,242$. Diketahui bahwa setelah diberikan whey protein pada jam ke 1 dan 24 setelah aktivitas eksentrik belum dapat meningkatkan kekuatan otot. Sedangkan hasil uji t berpasangan kekuatan otot tungkai kelompok perlakuan pada 1 jam dengan 72 jam setelah aktivitas eksentrik terdapat perbedaan yang bermakna dengan nilai $p=0,000$. Diketahui bahwa setelah diberikan whey protein pada 1 jam, 24 jam dan 48 jam setelah aktivitas eksentrik terjadi peningkatan rerata kekuatan otot.

Berdasarkan hasil tersebut, dapat disimpulkan bahwa asupan whey protein dapat mengurangi gejala kerusakan otot yang ditandai dengan berkurangnya penurunan kekuatan otot pada 72 jam setelah aktivitas eksentrik.

Tabel 4. Analisis Deskriptif Range of Motion Sendi Lutut (derajat)

\begin{tabular}{|l|l|l|}
\hline Kekuatan Otot Tungkai & K1 & K2 \\
\hline Pretest & $130,5 \pm 4,8$ & $131,2 \pm 5,3$ \\
\hline Posttest 1 & $124,7 \pm 5,6$ & $124,4 \pm 5,6$ \\
\hline Post test 2 & $123,4 \pm 5,7$ & $123,8 \pm 6,3$ \\
\hline Post test 3 & $123,7 \pm 5,2$ & $124,3 \pm 5,2$ \\
\hline Post test 4 & $125,3 \pm 6,3$ & $130,8 \pm 3,1$ \\
\hline
\end{tabular}

Berdasrkan tabel 4 terlihat bahwa analisis deskriptif data pada kelompok kontrol menyatakan bahwa terjadi penurunan ROM sendi lutut pada 1 jam, 24 jam, 48 jam dan 72 jam setelah aktivitas eksentrik. Namun pada 72 jam mengalami peningkatan dibandingkan dengan 1 jam, 24jam dan 48 jam setelah aktivitas eksentrik. Sedangkan pada kelompok perlakuan juga mengalami punurunan ROM sendi lutut pada 1 jam, 24 jam, 48 jam dan 72 jam setelah aktivitas eksentrik. Namun pada 72 jam setelah aktivitas eksentrik mengalami peningkatan dibandingkan dengan 1 jam, 24 jam dan 48jam setelah aktivitas eksentrik. 
JURNAL SPORTA SAINTIKA

P-ISSN 2502-5651

E-ISSN 2579-5910

Tabel 5. Paired Sampel T-Test ROM Sendi Lutut Kelompok Kontrol dan Perlakuan

\begin{tabular}{|l|l|l|}
\hline Variabel & \multicolumn{2}{|l|}{$\mathrm{p}$-value } \\
\cline { 2 - 3 } & $\mathrm{K} 1$ & $\mathrm{~K} 2$ \\
\hline Pre test-post test 1 & 0,000 & 0,000 \\
\hline Pre test-post test 2 & 0,000 & 0,000 \\
\hline Pre test-post test 3 & 0,000 & 0,000 \\
\hline Pre test-post test 4 & 0,000 & 0,013 \\
\hline Post test 1-post test 2 & 0,000 & 0,568 \\
\hline Post test 1-pos test 3 & 0,000 & 0,009 \\
\hline Post test 1-pos test 4 & 0,000 & 0,000 \\
\hline Post test 2-post test 3 & 0,000 & 0,002 \\
\hline Post test 2-post test 4 & 0,052 & 0,000 \\
\hline Post test 3-post test 4 & 0,000 & 0,000 \\
\hline
\end{tabular}

Berdasarkan tabel 5 terlihat bahwa pada kelompok perlakuan terjadi penurunan ROM sendi lutut setelah aktivitas eksentrik hal ini dapat dilihat dari hasil uji tberpasangan pre test dengan pos test 1 dengan hasil berbeda bermakna $(p=0,000)$. Hasil uji t berpasangan ROM sendi kelompok perlakuan pada 1 jam dengan 24 jam setelah aktivitas eksentrik menunjukkan tidak dapat perbedaan yang bermakna dengan nilai $p=0,568$. Diketahui bahwa 1 jam setelah aktivitas eksentrik, kelompok perlakuan diberikan asupan whey protein, dengan demikian dapat dikatakan bahwa pada 24 jam setelah pemberian whey protein belum dapat meningkatkan ROM sendi lutut. Kemudian uji t berpasangan ROM sendi lutut kelompok perlakuan pada 1 jam dengan 48 jam setelah aktivitas eksentrik juga tidak terdapat perbedaan yang bermakna dengan nilai $p=0,009$. Diketahui bahwa setelah diberikan whey protein pada jam ke 1 dan 24 setelah aktivitas eksentrik belum dapat meningkatkan ROM sendi lutut.

Sedangkan hasil uji t berpasangan ROM sendi kelompok perlakuan pada 1 jam dengan 72 jam setelah aktivitas eksentrik terdapat perbedaan yang bermakna dengan nilai $p=0,000$. Berdasarkan hasil tersebut, dapat disimpulkan bahwa asupan whey protein dapat mengurangi gejala kerusakan otot yang 
JURNAL SPORTA SAINTIKA

P-ISSN 2502-5651

E-ISSN 2579-5910

ditandai dengan berkurangnya penurunan ROM sendi pada 72 jam setelah aktivitas eksentrik.

Tabel 6. Hasil Uji t 2 Sampel Bebas Kekuatan Otot Tungkai dan ROM sendi lutut

\begin{tabular}{|l|l|l|}
\hline \multirow{2}{*}{ Delta } & \multicolumn{2}{|l|}{$p$-value } \\
\cline { 2 - 3 } & Kekuatan Otot Tungkai & ROM Sendi Lutut \\
\hline Delta 1 & 0,127 & 0,516 \\
\hline Delta 2 & 0,513 & 0,201 \\
\hline Delta 3 & 0,804 & 0,007 \\
\hline Delta 4 & 0,002 & 0,000 \\
\hline Delta 5 & 0,074 & 0,367 \\
\hline Delta 6 & 0,003 & 0,457 \\
\hline Delta 7 & 0,000 & 0,000 \\
\hline Delta 8 & 0,071 & 0,002 \\
\hline Delta 9 & 0,013 & 0,000 \\
\hline Delta 10 & 0,001 & 0,000 \\
\hline
\end{tabular}

Keterangan:

Delta 1 : selisih pre test - post test 1 kontrol dan perlakuan

Delta 2 : selisih pre test - post test 2 kontrol dan perlakuan

Delta 3 : selisih pre test - post test 3 kontrol dan perlakuan

Delta 4 : selisih pre test - post test 4 kontrol dan perlakuan

Delta 5 : selisih post test 1 - post test 2 kontrol dan perlakuan

Delta 6 : selisih post test 1 - post test 3 kontrol dan perlakuan

Delta 7 : selisih post test 1 - post test 4 kontrol dan perlakuan

Delta 8 : selisih post test 2- post test 3 kontrol dan perlakuan

Delta 9 : selisih post test 2- post test 4 kontrol dan perlakuan

Delta 10 : selisih post test 3 - post test 4 kontrol dan perlakuan

Pada tabel 6 dapat dilihat delta kekuatan otot tungkai 1 jam setelah aktivitas dengan sebelum aktivitas eksentrik antara kelompok kontrol dan perlakuan tidak berbeda bermakna dengan nilai $p=0,127$,. Pada saat 24 jam setelah aktivitas eksentrik, kekuatan otot tungkai antara kelompok kontrol dan (c) (i) (?) 
JURNAL SPORTA SAINTIKA

\section{P-ISSN 2502-5651}

E-ISSN 2579-5910

perlakuan juga tidak berbeda bermakna, hal ini ditunjukkan oleh delta 5 dengan nilai $p=0,074$. Sedangkan 48 jam setelah aktivitas eksentrik, kekuatan otot tungkai antara kelompok kontrol dan perlakuan didapatkan perbedaan yang bermakna, hal ini ditunjukkan oleh delta 6 dengan nilai $p=0,003$, pada saat 72 jam setelah aktivitas eksentrik kekuatan otot tungkai antara kelompok kontrol dan perlakuan berbeda secara bermakna, hal ini ditunjukkan oleh delta 7 dengan nilai $p=0,000$. Berdasarkan hal tesebut dapat dikatakan bahwa pemberian whey proteinsetelah aktivitas eksentrik dapat mengurangi gejala kerusakan otot yang ditandai dengan berkurangnya penurunan kekuatan otot tungkai pada 48 jam dan 72 jam dibandingkan dengan pemberian air mineral.

Delta ROM sendi lutut 1 jam setelah aktivitas dengan sebelum aktivitas eksentrik antara kelompok kontrol dan perlakuan tidak berbeda bermakna dengan nilai $p=0,516$, pada saat 24 jam setelah aktivitas eksentrik, ROM sendi lutut antara kelompok kontrol dan perlakuan juga tidak berbeda bermakna, hal ini ditunjukkan oleh delta 5 dengan nilai $p=0,367$. Pada 48 jam setelah aktivitas eksentrik, ROM sendi lutut antara kelompok kontrol dan perlakuan juga tidak berbeda bermakna, hal ini ditunjukkan oleh delta 6 dengan nilai $p=0,457$. Sedangkan pada saat 72 jam setelah aktivitas eksentrik, didapatkan ROM sendi lutut antara kelompok kontrol dan perlakuan berbeda secara bermakna, hal ini ditunjukkan oleh delta 7 dengan nilai $p=0,000$. Dengan demikian, dapat disimpulkan bahwa asupan whey protein setelah aktivitas eksentrik dapat mengurangi gejala kerusakan otot yang ditandai dengan berkurangnya penurunan ROM sendi lutut pada 72 jam dibandingkan dengan pemberian air mineral.

\section{PEMBAHASAN}

Hasil penelitian menunjukkan bahwa rerata kekuatan otot tungkai sebelum aktivitas eksentrik (pre test) pada kelompok kontrol dan perlakuan dikatakan dalam kategori sangat baik yaitu dengan rerata sebesar $74,47 \pm 19,4$ pada kelompok kontrol dan $82,5 \pm 16,4$ pada kelompok perlakuan. Seseorang dikatakan memiliki kekuatan otot tungkai yang sangat baik apabila nilai kekuatan otot tungkainya $>54,50$ (Kemenpora, 2009). Nilai kekuatan otot tungkai yang 
JURNAL SPORTA SAINTIKA

\section{P-ISSN 2502-5651}

E-ISSN 2579-5910

sangat baik pada kedua kelompok tersebut memberikan suatu gambaran bahwa kondisi awal dari kedua kelompok sama.

Exercise-induced muscle damaged atau kerusakan otot akibat latihan merupakan fenomena yang umum terjadi setelah latihan yang tidak terbiasa atau latihan dengan intensitas dan durasi yang meningkat (Byrne et al, 2004). Kerusakan otot merupakan kegagalan setiap tingkat mempertahankan keseimbangan antara paparan stres dengan respon terhadap stres. Kegagalan di tingkat atomik menyebabkan kerusakan di tingkat molekuler, kegagalan di tingkat molekul menyebabkan kerusakan di tingkat seluler dan kegagalan di tingkat seluler menyebabkan kerusakan di tingkat jaringan. (Purwanto, 2013). Burnley et al. (2010) mengatakan bahwa gejala- gejala kerusakan otot yang umumnya terjadi akibat latihan meliputi nyeri (soreness), penurunan kekuatan otot, penurunan range of motion ( $\mathrm{ROM})$, peningkatan respons inflamasi, peningkatan jumlah serum creatine phosphokinase dalam darah. Dalam kaitanya terhadap aktivitas fisik atau latihan yang berdampak pada timbulnya gejala-gejala kerusakan otot serta membutuhkan waktu pemulihan paling lama, dikatakan bahwa jenis latihan yang menggunakan high-force eccentric muscle actions seperti latihan tahanan (resistance), plyometrics serta downhill running dapat menimbulkan kerusakan otot. (Street et al., 2011).

Hasil penelitian mengenai kekuatan otot tungkai 1 jam (post test1), 24 jam (post test 2), 48 jam (post test 3) dan 72 jam (post test 4) setelah aktivitas eksentrik menunjukkan bahwa terdapat penurunan pada kedua kelompok jika dibandingkan dengan rerata kekuatan otot tungkai pre test pada masing- masing kelompok. Hal ini menunjukkan bahwa aktivitas eksentrik yang diberikan dapat menyebabkan penurunan kekuatan otot tungkai pada masing-masing kelompok. Tidak ada perbedaan bermakna pada delta kekuatan otot tungkai sebelum (pre test) dengan 1 jam setelah aktivitas eksentrik (post test 1) antara kelompok kontrol dan perlakuan. Kondisi demikian memberikan suatu gambaran bahwa penurunan kekuatan otot tungkai yang terjadi pada kedua kelompok adalah seimbang dan pemberian whey protein pada kelompok perlakuan baru diberikan setelah post test 1 .

Kerusakan serabut otot akibat latihan yang melibatkan pemanjangan otot akan memicu serangkaian reaksi dan interaksi yang kompleks diantara sintesis 
JURNAL SPORTA SAINTIKA

P-ISSN 2502-5651

E-ISSN 2579-5910

dan degradasi protein. Pergantian protein (protein turnover) meningkat pesat, tingkat degradasi protein akan mengalahkan laju sintesis protein, sehingga terjadi peningkatan dalam penguraian protein otot (muscleprotein breakdown) yang mengakibatkan degenersi otot. Perubahan dalam ultrastruktur protein ini yang umumnya menyebabkan gejala fisiologis seperti penurunan kekuatan otot, nyeri otot, dan terganggunya fugsi otot (Cooke et al., 2010). Rangsangan sintesis protein dan meminimalisasi muscleprotein breakdown (proteolisis) adalah dua proses seluler yang penting untuk pemulihan setelah kerusakan otot (Rennie et al, 2006). Meningkatkan laju sintesis protein setelah latihan eksentrik penting dalam mencapai positive net muscle protein balance atau keseimbangan protein otot yang positif. Keseimbangan protein otot yang positif diperlukan selama waktu tertentu untuk mengganti protein otot yang rusak ataupun untuk membangun otot (Jackman, 2011).

Hasil uji statistik menunjukkan perbedaan yang bermakna pada kekuatan otot tungkai antara kelompok kontrol dan perlakuan pada 48 jam dan 72 jam setelah aktivitas eksentrik. Perbedaan yang bermakna tersebut diduga oleh karena asupan whey protein yang diberikan pada 1 jam 24 jam dan 48 jam setelah aktivitas eksentrik pada kelompok perlakuan. Pemberian suplemen whey protein setelah sesi latihan eksentrik akan meningkatkan pengiriman asam amino ke dalam otot sehingga dapat meningkatkan sintesis protein dan meminimalkan degradasi protein sehingga menghasilkan penurunan kekuatan otot yang lebih kecil serta mempercepat pemulihan kerusakan otot (Cooke et al., 2010).

Apabila terjadi sintesis protein jaringan, baik untuk penggantian atau penambahan, sel harus memiliki semua asam amino- asam amino yang diperlukan secara bersamaan baik asam amino nonesensial maupun asam amino esensial. ). Semua unsur dalam kandungan whey protein menyediakan asam amino dan kaya akan BCAA (Branched Chain Amino Acids) yang berperan penting untuk sisntesis protein otot dan pemulihan (Hoffman \& Falvo, 2004). Asupan protein seperti whey protein ini juga akan merangsang pengeluaran hormon pertumbuhan (growth hormone). Apabila kadar protein dalam darah mengalami peningkatan maka akan merangsang hormon pertumbuhan untuk meningkatkan transpor asam amino ke dalam sel otot (Marks et al., 2000). Terjadinya peningkatan dalam sintesis protein otot dan penurunan pada 
JURNAL SPORTA SAINTIKA

P-ISSN 2502-5651

E-ISSN 2579-5910

penguraian protein otot (muscleprotein breakdown) akan menghasilkan keseimbangan protein otot yang positif atau positive net muscle protein balance (Hulmi et al, 2010). Keseimbangan protein otot yang posltif diperlukan selama periode tertentu untuk mengganti protein otot yang rusak ataupun untuk membangun protein otot (regenerasi). Regenerasi otot sangat penting untuk membantu mengurangi penurunan kekuatan otot setalah latihan eksentrik (Jackman, 2011).

Range of motion (ROM) sendi merupakan maksimum gerak yang mungkin dilakukan sendi pada salah satu dari tiga potongan tubuh: sagital, frontal dan transversal. ROM sendi dalah gambaran tentang seberapa banyak pergerakan yang dimiliki oleh sendi (Potter \& Perry, 2006). Menurut Kozier (2004), ROM diartikan sebagai pergerakan maksimal yang dimungkinkan pada sebuah persendian tanpa menyebabkan rasa nyeri. ROM merupakan salah satu indikator fisik yang berhubungan dengan fungsi pergerakan (Easton, 1999). ROM sendi dapat diukur baik secara aktif ataupun pasif. Aktif ROM dilakukan dengan kontraksi otot disekitar sendi oleh diri sendiri atau tanpa bantuan dari luar. ROM pasif dilakukan oleh kekuatan eksternal dengan cara mendorong daerah tubuh sekitar sendi (Luttgens \& Hamilton, 1997). Pada penelitian ini pemeriksaan ROM sendi lutut orang coba dilakukan dengan cara pasif.

Hasil penelitian menunjukkan bahwa rerata ROM sendi lutut sebelum aktivitas eksentrik (pre test) pada kedua kelompok penelitian dikatakan dalam kategori normal yaitu dengan rerata sebesar $130,5 \pm 4,8$ derajat pada kelompok kontrol dan $131,2 \pm 5,3$ derajat pada kelompok perlakuan. Seseorang dikatakan memiliki ROM sendi yang normal apabila nilai ROM sendi lututnya 130-145 derajat (Norkin et al., 2009). Kondisi demikian memberikan suatu gambaran bahwa kekuatan otot tungkai pre test pada kedua kelompok mempunyai nilai yang sama.

Hasil penelitian mengenai ROM sendi lutut1 jam (post test1), 24 jam (post test 2), 48 jam (post test 3) dan 72 jam (post test 4) setelah aktivitas eksentrik menunjukkan bahwa terdapat penurunan pada kedua kelompok jika dibandingkan dengan rerata ROM sendi lutut pre test pada masing- masing kelompok. Hal ini menunjukkan bahwa aktivitas eksentrik yang diberikan dapat menyebabkan penurunan ROM sendi lutut pada masing-masing kelompok. Tidak 
JURNAL SPORTA SAINTIKA

P-ISSN 2502-5651

E-ISSN 2579-5910

ada perbedaan bermakna pada delta ROM sendi lutut sebelum (pre test) dengan 1 jam setelah aktivitas eksentrik (post test 1) antara kelompok kontrol dan perlakuan. Kondisi demikian memberikan suatu gambaran bahwa penurunan ROM sendi lutut yang terjadi pada kedua kelompok adalah seimbang dan pemberian whey protein pada kelompok perlakuan baru diberikan setelah post test 1.

Selama kontraksi otot yang memanjang (eksentrik) akan meregangkan sarkomer pada setiap serat otot. Pemanjangan pada sarkomer juga menyebabkan retikulum sarkoplasma teregang dan mengeluarkan subtansi ion kalsium (Ca2+). Pelepasan substansi ion kalsium yang terjadi ketika kontraksi eksentrik menyebabkan konsentrasi $\mathrm{Ca}+$ di dalam sitoplasma sel otot meningkat. Sehingga mengakibatkan gangguan pada homeostatis ion kalisum intraselular. Ion kalsium di dalam sitosol meningkat pada saat kontraksi otot, makin tinggi intensitas kontraksi makin banyak ion kalsium berada di sitosol (Effendi, 2012). Meningkatnya kadar Ca2+ dalam intraseluler juga dapat menyebabkan lebih banyaknya formasi cross bridge sehingga mengurangi fase relaksasi kontraksi otot. Penurunan dalam fase relaksasi kontraksi otot dapat menjadi penyebab dari kekakuan otot serta penurunan ROM sendi setelah latihan eksentrik (Jackman, 2011). Terjadinya pembengkakan, peradangan serta gangguan pada myofibril setelah latihan latihan eksentrik menyebabkan peningkatan kekakuan otot pasif sehingga terjadi penurunan ROM pada sendi pada otot yang terekena (Willoughby 2003).

Hasil uji statistik menunjukkan perbedaan yang bermakna pada ROM sendi lutut antara kelompok kontrol dan perlakuan pada 72 jam setelah aktivitas eksentrik. Perbedaan yang bermakna tersebut diduga oleh karena asupan whey protein yang diberikan pada 1 jam, 24 jam serta 48 jam setelah aktivitas eksentrik pada kelompok perlakuan. Whey protein mengandung banyak pasokan asam amino sistein. Sinstein diperlukan untuk meningkatkan kadar glutathione (Counous, 2000). Glutathione memiliki sifat antioksidan yang berguna untuk mengurangi inflamasi setelah latihan eksentrik sehingga dapat mengurangi nyeri otot dan kekakuan otot. Berkurangnya rasa nyeri dan kekauan otot dapat berdampak positif pada ROM sendi lutut. Penelitian yang dilakukan oleh Jackman (2011) menyatakan bahwa pemberian whey protein selama tiga hari 
JURNAL SPORTA SAINTIKA

\section{P-ISSN 2502-5651}

E-ISSN 2579-5910

masa pemulihan dapat mengurangi nyeri otot setelah latihan eksentrik. ROM sendi juga dipengaruhi beberapa faktor, seperti mobilitas kapsul sendi dan ligamen, fascia, serta kekuatan otot (Luttgens \& Hamilton, 1997). Berkurangnya penurunan kekuatan otot tungkai setelah diberikan asupan whey protein nampaknya juga mempengaruhi pengurangan pada penurunan ROM sendi lutut kelompok perlakuan.

\section{KESIMPULAN}

Berdasarkan analisis data hasil penelitian dan pembahasan yang telah diuraikan sebelumnya, maka dapat disimpulkan bahwa pemberian suplemen whey protein dapat menurunkan pengurangan gejala kerusakan otot yang ditandai dengan peningkatan kekuatan otot tungkai pada 48 jam dan 72 jam serta peningkatan ROM sendi pada 72 jam setelah aktivitas eksentrik.

\section{SARAN}

Berdasarkan kesimpulan yang telah dikemukakan diatas, maka disarankan :

1. Perlu diteliti mengenai efek pemberian whey protein terhadap radikal bebas yang merupakan salah satu pemicu kerusakan otot setelah latihan eksentrik

2. Perlu dilakukan penelitian serupa dengan menggunakan beberapa dosis yang berbeda guna mengetahui proses pemulihan secara menyeluruh.

3. Perlupenelitianserupadenganmenggunakanpengukuran secara langsung dengan menggunakan biopsi otot, serta magnetic resonance imaging techniques (MRI), sebagaigambaran yang lebihspesifik mengeneikerusakanototsetelahaktivitas

\section{DAFTAR PUSTAKA}

Bompa T, 1999. Periodezation training for sport: progam for peak strength in 35 sport. United States America: Human kinetic.

Burnley DE, Angela NO, Sharp RL, Bailer SW, Alekel DL. 2010. "Impact of protein suplements on muscle recovery after exercise-induced muscle soreness". Journal Exercise Science Fitness. 8: 89-96.

Byrne C, Twist C, Eston R. 2004. "Neuromuscular function after exercise induced muscle damage: theoritical and applied implications". Journal Sport Medicine. 34: 49-69. 
JURNAL SPORTA SAINTIKA

P-ISSN 2502-5651

E-ISSN 2579-5910

Castro AP, Vianna JM, Damasceno VO, Matos DG, Filho ML. 2011."Muscle recovery after session of resistance training monitored through serum creatin kinase". Journal exercise Physiology. 14: 38-45.

Cooke MB, Rybalka E, Stahis GC, Cribb JP, Hayes Alan. 2010. "Whey protein isolate attenuates strength decline after eccentrically-induced muscle damage in healthy individuals". Journal of the International Society of Sport Nutrition. 7:2-9.

Easton, K. 1999. Gerontology rehabilitation nursing, W.B. Saunders Company. Philadelphia.

Effendi, C., Santoso, K.P., Purwanto, B. 2009. Buku ajar faal sel, cair tubuh, saraf tepi, dan otot. Departemen Ilmu Faal, Universitas Airlangga.

Ha, E. and Zemel, M.B. 2003 . "Functional properties of whey, whey components, and essential amino acids: Mechanisms Underlying health benefits for active people". Journal of Nutritional Biochemistry 14, 251-258.

Hoffman R Jay, Falvo MJ. 2004. "Macronutrient utilization during exercise implications for performance and supplementation; Protein-which is best? ". Journal of Sports Science and Medicine 3: 118-130

Hulmi JJ, Lockwood CM, Stout JR. 2010. "Effect of protein-essential amino acids and resistance training on skeletal muscle hypertrophy : A case for whey protein". Nutrition and Metabolism. 7: 51.

Jackman SR. 2011. "Whole body and muscle response to protein and branched chain amino acid feeding following intense exercise". Exercise Metabolism Research Group. School of Sport and Exercise Sciences. University of Birmingham.

Kauranen K, Kiinira P, heikii V.2001. "Delayed onset muscle soreness and motor performance of the upper extremity". Europe Journal Apllied Physiology. 84: 302-309.

Kozier, B., Erb, G. and Blais, K. 2004. Fundamental of nursing concepts, process and practice. Addison Wesley Publishing. Company Inc, California.

Luttgens, K. \& Hamilton, N. 1997. Kinesiology: Scientific basis of human motion, 9th Ed. Madison, WI: Brown \& Benchmark.

Marks DB, Marks AL, Smith CM, 2000. Biokimia kedokteran dasar: sebuah pendekatan klinis. Terjemahan oleh Pendit Brahm. Jakarta: Gajah Mada University Press

Purwanto B. 2013. Mekanisme kerja curcumin dalam mencegah kerusakan otot rangka mencit yang melakukan aktivitas eksentrik sesaat. Disertasi Fakultas Kedokteran Univ. Airlangga.Surabaya.

Rennie MJ and Tipton KD. 2000. "Protein and amino acid metabolism during and after exercise and the effect of nutrition“. Annual Reviews Nutrition. 20 : 457-483.

Street B, Chrystoper B, Reger R. 2011. "Glutamine supplementation in recovery from eccentric exercise attenuates strength loss and muscle damage". Journal exrecise sience fitness. 9: 116-122.

Tipton KD, Elliott TA, Cree MG, Aarsland AA, Sanford AP, and Wolfe RR. 2009. "Stimulation of net muscle protein synthesis by whey protein ingestion before and after exercise". Am J Physiol Endocrinol Metab 292: E71-76.

Willoughby DS, Clesivanenk, Lemuel Taylor. 2003. "Effects of concentric and eccentric contractions on exercise- induced muscle injury, inflamation and 
JURNAL SPORTA SAINTIKA

P-ISSN 2502-5651

E-ISSN 2579-5910

serum IL-6“. Journal of The American Society of Exercise Physiologists. Vol 6.

Zaiuddin M, 2011. Metodologi penelitian. Surabaya. 